\title{
Festskrift till Per
}

HumaNetten är en tidskrift som spänner över de många fält och intresseområden som ryms inom Fakulteten för konst och humaniora vid Linnéuniversitetet. Många av fakultetens medarbetare har verkligen vetenskapliga tentakler som rör sig över ämnesgränserna, och så är även fallet med den den person som detta nummer är tillägnat. Det ni ser framför er på bildskärmen är nämligen en festskrift tillägnad Per Stille, docent i svenska språket med arbetsplats i Växjö. Bredden på Pers intressen återspeglas i de bidrag som hans vänner och kollegor författat i samband med Pers pensionering: runologi, nordisk filologi, arkeologi, religionsvetenskap, kulturhistoria.

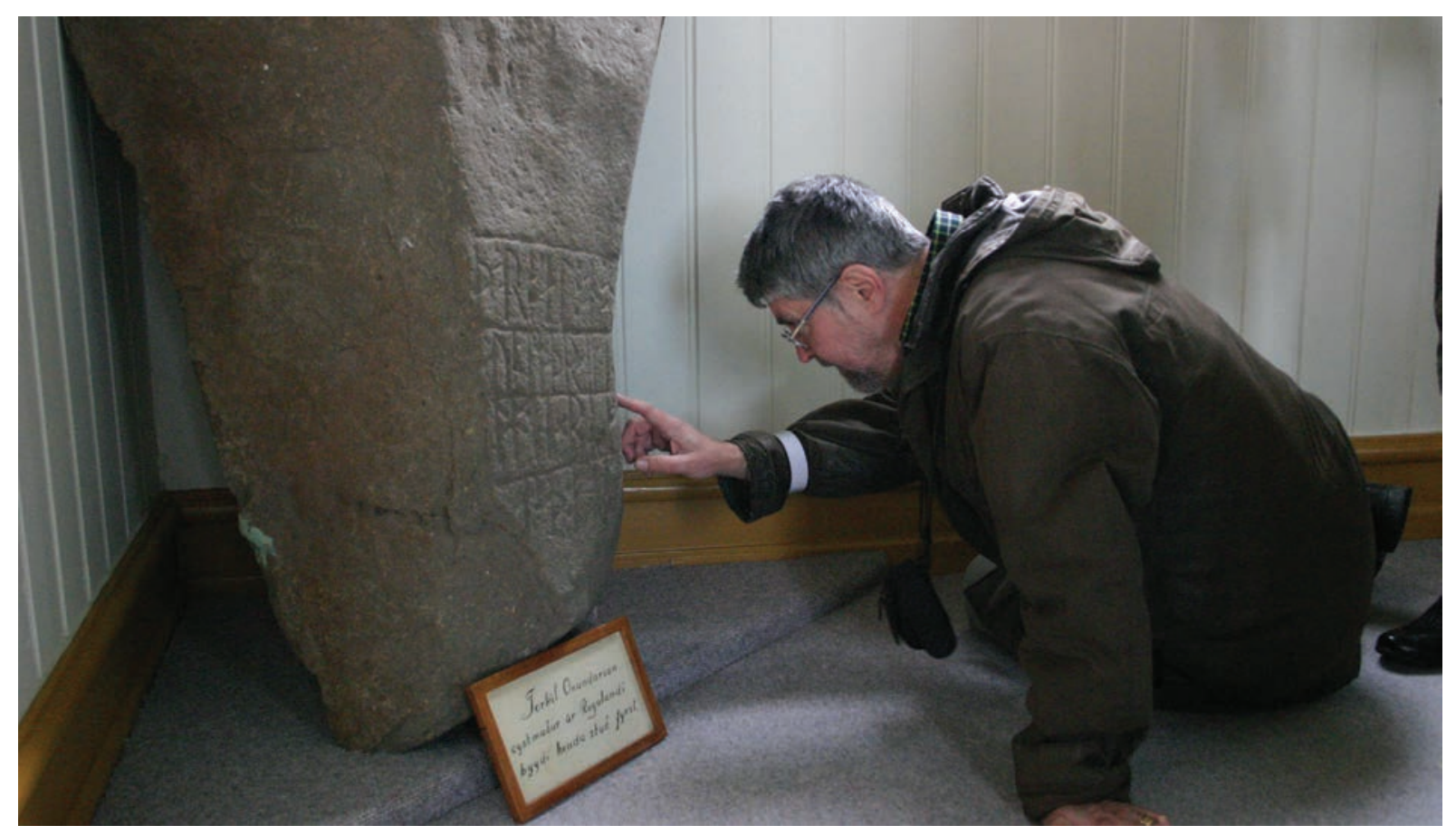

Per Stille läste teologi i Uppsala när det begav sig vilket bland annat resulterade i skriften “...lämna en efterskörd": en roll- och koherensanalys av Obadja och Jeremia 49.7.22 (Uppsala 1988). Hans verkliga håg stod emellertid till runologin. Pers första större bidrag var "Gunnarsstenarna": en studie över några mellansvenska runstensgruppers distribution i tid och rum (Uppsala 1989) som följdes av doktorsavhandlingen Runstenar och runristare i det vikingatida Fjädrundaland: en studie i attribuering (Uppsala 1999). Som en del av bidragen i detta nummer klart visar har Pers grundarbete när det gäller runstenars attribuering stått sig och haft stor betydelse för vidare efterforskningar. Vid Växjö universitet (från 2010 Linnéuniversitetet) gjorde han sig under en decennielång vistelse känd som en mycket uppskattad och omtyckt kollega. Under flera år drev Per tillsammans med undertecknad en seminarieserie för äldre historiska och filologiska frågor, "Kultur - språk - historia“ där några av bidragsgivarna till denna festskrift har gästspelat. Vi ser med saknad på hans pensionering vid 65 års ålder och hoppas på många aktiva år som forskare emeritus. 
De elva bidragen publiceras här i okomplicerad alfabetisk ordning. Fem av dem, av Martin Hansson (Lunds Universitet), Magnus Källström (Riksantikvarieämbetet), Patrik Larsson (Högskolan i Dalarna), Michael Lerche Nielsen (Köpenhamns universitet) och Henrik Williams (Uppsala universitet), berör Pers huvudfält runologi, fast ur mycket olika perspektiv. Här finns tolkningar och attribueringar av runstenar liksom en studie av en runstens närmiljö, en analys av runnamn och en betraktelse över runstenen på Tegnérstatyn i Lundagård. Tre ytterligare bidrag, av Gunilla Byrman (Linnéuniversitetet), Gunilla Söderberg (Linnéuniversitetet) och Bo Wendt (Lunds universitet), studerar ord i språket och deras historia; det gäller så skilda begrepp som 'duktig', 'näktergal' och 'va?’ En essä av Påvel Nicklasson (Lunds Universitet) förklarar Lundaprofessorn Sven Nilssons bekantskap med Bländaland, det vill säga Värend. Didaktiska perspektiv öppnas i en betraktelse av Maria Lindgren och Sofia Ask (bägge Linnéuniversitetet). Och en studie av Torsten Löfstedt (Linnéuniversitetet) refererar en debatt om hur Judas egentligen uppfattades av de nytestamentliga författarna.

Växjö i blomstertid

Hans Hägerdal

Ordförande i redaktionsrådet 